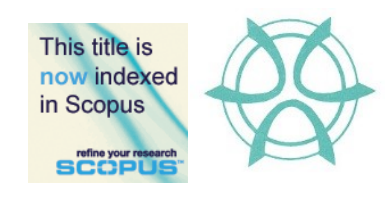

\title{
WORKING COMMUNITIES' SIGNIFICANT HERITAGE URBAN RIVER CORRIDOR LANDSCAPE OF MELAKA CITY
}

\author{
Nor Arbina Zainal Abidin ${ }^{1}$, Debra Flanders Cushing ${ }^{2}$, Gillian Lawson ${ }^{3}$ \\ ${ }^{1}$ School of Housing, Building and Planning, \\ UNIVERSITI SAINS MALAYSIA \\ ${ }^{2}$ School of Design, \\ QUEENSLAND UNIVERSITY OF TECHNOLOGY \\ ${ }^{3}$ Faculty of Environment, Society and Design, \\ LINCOLN UNIVERSITY
}

\begin{abstract}
The existing landscape characters of urban river corridor of Melaka City have eroded due to unsustainable design outcomes due to inadequate policies and guidelines, indiscriminate decision in design and it lacks of community consultation. In addition, political intervention and climate change have made it worse to the present urban river corridor of the city. These issues have raised concerns among the local community, particularly those workers whose livelihood depend on resources in that area. This paper reveals the distribution patterns and landscape settings of the urban river corridor of Melaka City which are significant among working communities. It also describes each landscape setting within the identified territory. The findings are determined via thematic coding analysis and overlay mapping technique based on the experiential landscape theory established by Thwaites and Simkins (2007). The combination of experiential landscapes from different individuals via overlay mapping analysis also provides insight into the communities' urban river corridor boundary of the city, which is important in heritage-related policy.
\end{abstract}

Keywords: Landscape Character, Urban River Corridor, Working Communities of Urban River Corridor, Experiential Landscape, Melaka City

\footnotetext{
${ }^{1}$ Corresponding Author \& Lecturer at Universiti Sains Malaysia. Email: arbina@usm.my
} 
Nor Arbina Zainal Abidin, Debra Flanders Cushing and Gillian Lawson

Working Communities' Significant Heritage Urban River Corridor Landscape of Melaka City

\section{INTRODUCTION}

The landscape character of Sungai Melaka is significant to the livelihood of the urban river corridor working communities, thus the state government strives to improve this area to serve their needs, encompassing the working, living and recreational aspects (Rustam, 2007, 2008; Salim, Othman, Mohamed, \& Ismail, 2012; SMHB, 2010). The status as the "Historic City of the Straits of Malacca" UNESCO on 7 July 2008 has stimulated regional growth in this Malaysian heritage river city (Rustam, 2008). This recognition has encouraged the state government of Melaka to build more tourist attractions within the river corridor territory to generate employment opportunities and improve the quality of the area with Sungai Melaka as the main attraction. Often, the local urban design teams face difficulty in developing a suitable yet sustainable design within the city's river corridor due to inadequate development policies and guidelines pertaining to river corridor, coupled with the issue of climate change. There are more challenges for the teams due to political intervention and inconsistent resolution during the design process.

Recently, there are feedbacks from the public in the local mainstream media, of the development of the modern urban landscape attractions and infrastructure has overshadowed the natural and existing heritage landscape and historical artefacts in Melaka City and its surrounding river corridor. The studies on the feasibility of the urban river corridor development in Melaka City are limited, particularly in the context of landscape design (Mohamad, Toriman, Aiyub, \& Jaafar, 2005; Nordin, 1998; SMHB, 2010). Also, there are limitations to the current approaches in finding the core users whose livelihood and working routines are dependent on the resources around the urban river corridor of Melaka City. These core users have a unique experience and understanding of working and/or living in the urban river corridor settings, this can aid the urban design teams to make decision in the development projects undertaken for this place. Indeed, these processes are essential in the sustainability of the development and to maintain the highly regarded and valued existing landscape character.

\section{RESEARCH BACKGROUND}

According to the Riverfront Development Guidelines outlined by the Department of Irrigation and Drainage Malaysia (DID), a river corridor is defined as, "the river, including the area extending fifty (50) meters beyond the river reserve on both sides" (Refer Figure 1). This sets out the basic form and position of river corridor, overlooking the ecological and dynamic characteristics, which are essential in defining the territory of the strips of land along river channels.

A river corridor boundary is complex and difficult to determine, as the territory does include diverse landscape settings and living systems that rely on and connected to the river (Forman, 1995). Yet, the perception of river corridor boundary among the urban design teams in Malaysia from 1990s to early 2000s 
remains the same. Therefore, similar designs and approaches applied in most of the urban river corridors and riverfront property developments in the country. The disregard of the dynamic and complex ecological characteristics of river corridors in designing process and limited enforcement of design outcomes have rendered urban river corridor developments in Malaysia unsustainable and of poor quality.

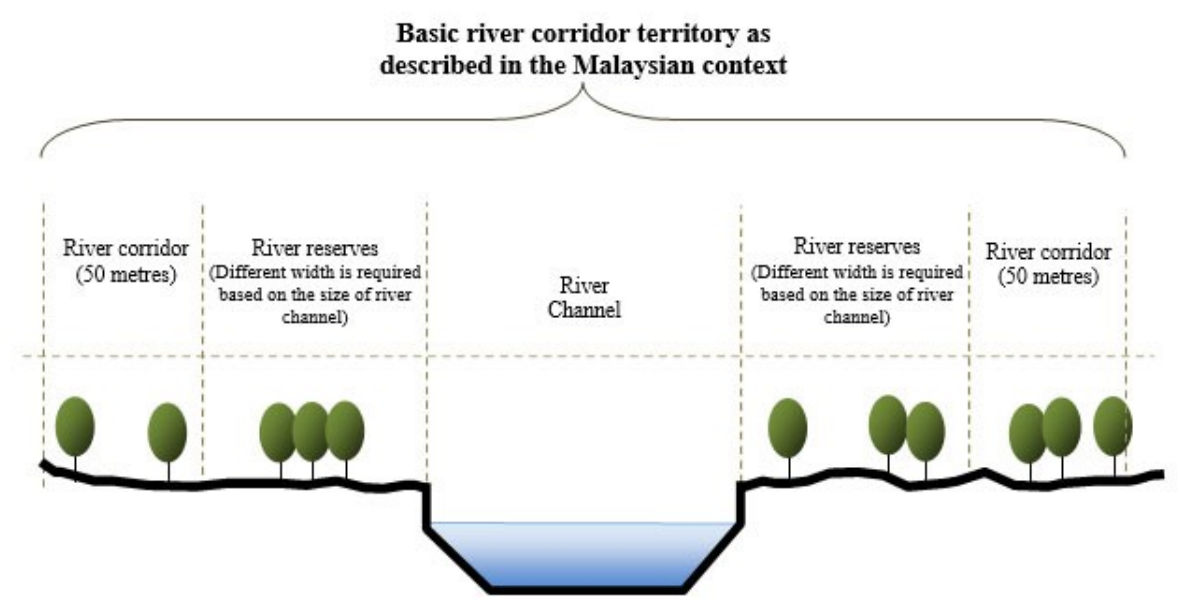

Figure 1: Urban river corridor territory according to the Department of Irrigation Malaysia (DID).

Source adapted from DID Malaysia (2006)

There are also limitations to the current approaches used to aid the process of finding core users whose livelihoods and working routines are much dependent on the values offered by their urban river corridors. Yet, their long and unique experience and understanding about the settings can aid urban design teams' decision making in development and improvement projects undertaken for these particular settings. Therefore, this study argues that it is important to access the knowledge, experience and viewpoints of these types of stakeholders, who can potentially influence the quality and sustainability of landscape design outcomes, particularly that need to be established on a dynamic yet fragile area in our heritage urban area such as on urban river corridor of Melaka City. It is also essential for urban design teams in Malaysia to strengthen their current landscape design process to gain more comprehensive and holistic design solutions that are influenced by meaningful community consultation.

This paper attempts to reveal the findings of the distribution patterns of working communities' important yet significant landscape settings of heritage urban river corridor in Melaka City context. All these crucial experiential landscape settings are categorized using the spatial components of Experiential 
Nor Arbina Zainal Abidin, Debra Flanders Cushing and Gillian Lawson

Working Communities' Significant Heritage Urban River Corridor Landscape of Melaka City

Landscape, which defined by Thwaites and Simkins (2007b) as Centre, Direction, Transition, and Area. The study has also led to the identification of urban river corridor territory that is meaningful to a diverse range of working communities for Melaka City.

\section{METHODS}

This study applied qualitative research approach. It involved exploring landscape experience from a diverse range of local people representing working communities from casual workers to professional people. This study has also selected from a diverse range of socio-economic backgrounds and which their scope of work and working routines are connected and depend on resources offered by urban river corridor of Melaka City. Specifically, this study identifies various occupations practiced by insiders in the urban river corridor of Melaka City as shown in Figure 1. The selection of the urban river corridor of Melaka City as a case study was based on the following existing characteristics:

- The river corridor is significant in historical, ecological, physical and cultural development contexts;

- The river corridor is a living niche for their local communities who came from diverse socio-cultural and socio-economic backgrounds;

- The river of the city is significant in influencing the physical development, socio-economic and living culture of the people; and,

- It located at the estuary area, within the jurisdiction of established city council management, experienced rapid urbanization, possess distinctive tourism and cultural-based development orientation; and, experienced active urban landscape design and development activities.
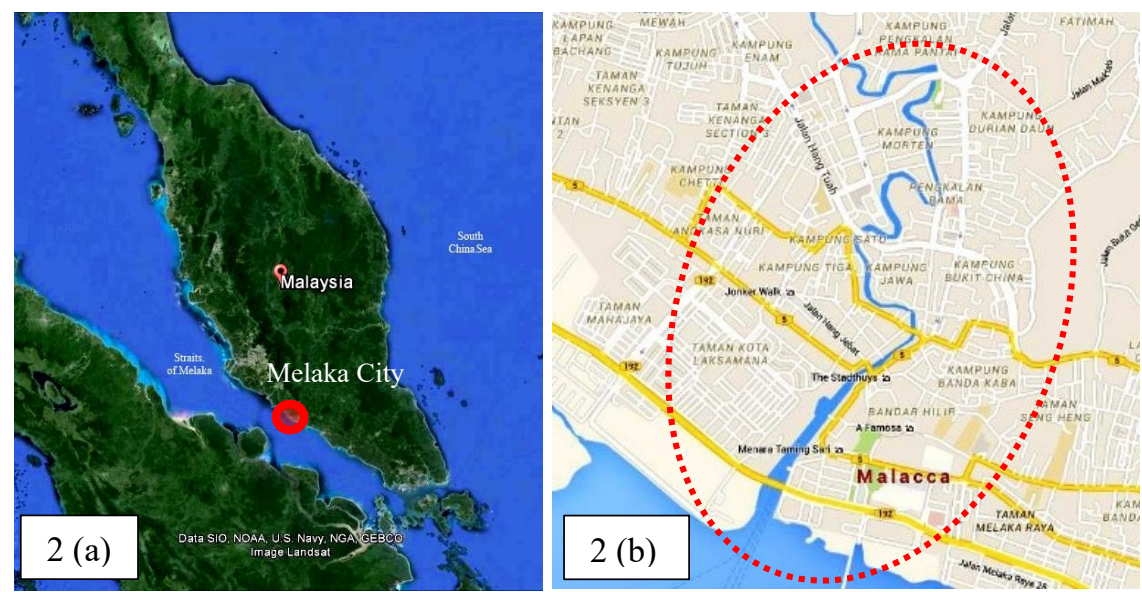

Figure 2 (a): The location of Melaka City in Peninsular Malaysia (left). 
Figure 2 (b): The study area of the urban river corridor in Melaka City (right). Source: Google Earth (2017)

This study has undertaken the three significant processes for assessing the important landscape character settings of urban river corridors via human experience, as shown in Figure 3. These processes including:

i) Defining preliminary boundaries for research areas;

ii) Focusing on tracking the workplace for selected occupations that depended on urban river corridor resources as well as finding relevant individuals representing the selected occupations with working routine and experience within the setting; and,

iii) Identifying and assessing important settings perceived by these selected individuals representing working communities of the studied area.

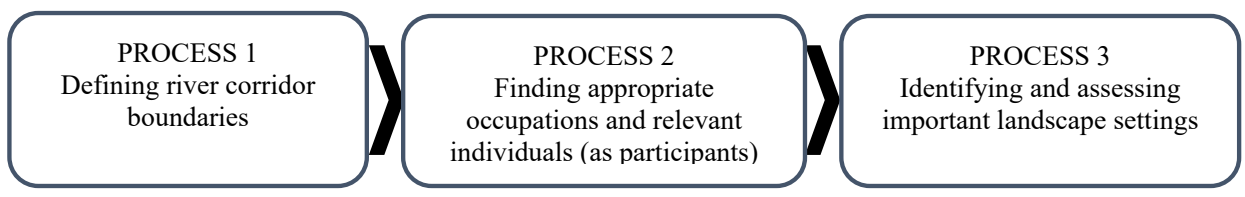

Figure 3: The flow of the three major processes for this research

Defining the preliminary boundary of urban river corridor of Melaka City that was done in Process 1 is crucial. It is essential to support the identification of key people among insiders of the place who further will be invited as a research participant for this study which this identification activity will be undertaken in Process 2. This study had used abundance information from the Internet in discovering distinct areas within the heritage urban river corridors that are potentially significant and valuable to insider communities. Specifically, it led the researcher towards preparing specific approaches to aid the first phase of fieldwork activities - to search which occupations and relevant individuals for research participants within the targeted groups - urban design team and special interest public. Process 1 was conducted earlier before the first stage of fieldwork activity take place. Process 1 involved exploring, collecting and gathering information about the research areas via the Internet and local publications. Online exploration and familiarization as part of analysis activities have been conducted at this stage. Several areas of significance were identified and the preliminary boundary for the urban river corridor of Melaka City was established.

Process 2 was conducted to identify possible occupations and relevant individuals as research participants via onsite exploration and familiarization 
Nor Arbina Zainal Abidin, Debra Flanders Cushing and Gillian Lawson

Working Communities' Significant Heritage Urban River Corridor Landscape of Melaka City

during the first stage of the fieldwork activities in Melaka City. There were four stages of activities in this Process 2 including:

i) Define purpose, scope \& prepare for field study 1;

ii) Field first impression experience;

iii) Field exploration \& familiarization to find appropriate occupations and,

iv) Identify relevant participants. This research has employed various transportation modes including walking, driving and riding popular public transport available at the site including river cruise boat and trishaw.

Table 1 shows the types of occupations representing working communities from the groups of urban design team and special interest public who have been identified through various tracking techniques during the first stage of site visit.

Table 1. Identified types of occupations.

\begin{tabular}{|c|c|}
\hline Working communities & $\begin{array}{c}\text { Techniques used to track down relevant occupations and people } \\
\text { Urban river corridor of Melaka City }\end{array}$ \\
\hline Urban Design Team & $\begin{array}{l}\text { - Courtesy visit \& casual conservation with urban manager team at Melaka } \\
\text { City Council }\end{array}$ \\
\hline Special Interest Public & $\begin{array}{l}\text { - Review local publication } \\
\text { - On-site exploration and observation } \\
\text { - Experiencing the service offered by service providers } \\
\text { - Casual conversation }\end{array}$ \\
\hline
\end{tabular}

Different groups of the working community of Melaka City have many reasons for depending on, appreciating and developing their sense of attachment to the studied urban river corridor landscape. In Process 3, the researcher thus undertook four stages of activities to search and assess the community's important urban river corridor landscape settings at Melaka City:

Stage 1: Strategize Experiential Landscape Survey (ELS) activities;

Stage 2: Create ELS brief and design tour;

Stage 3: Field study- administer ELS with participants; and

Stage 4: Classify and describe the important urban river corridor setting.

The above stages in Process 3 were vital for leading to the following findings:

i) the most to the least types of important landscape settings that are significant to the working insider community;

ii) the characteristics of the settings;

iii) the value and meanings of the landscape settings perceived by different groups of the working insider community; and

iv) the distribution of the settings within the studied urban river corridor landscape. 
This research employed thematic coding analysis and map overlay to analyze the in-depth interview from ELS data for the identification of important settings that are based on the experiential landscape theory established by Thwaites and Simkins (2007a). The main spatial components of experiential landscape theory including center, direction, transition and area.

\section{FINDINGS}

Urban manager, city journalist, tourist guide, boat skipper, and rickshaw puller are the five (5) main occupations that were found significant to support the study. Five (5) individual insiders representing the five types of identified occupations were found to be the most relevant research participants based on the values that they have long developed with the studied area. These five individuals have been carried outstanding experiences and hold close connections with the studied urban river corridor, which they have developed through their working routine within the place. Most of them were verbally and highly recommended by their colleagues in their respective working communities.

The opinions, feelings, and perceptions from a non-Muslim participant are significant to gather in-depth information (regarding the research area) from different points of view and cultural/ethnic group. Also, it provides a variety of meanings and experiences about the studied urban river corridor. Moreover, nonMuslim community is also involved and contribute to the evolution and growth of the settings. Table 2 shows the difference regarding participants' occupation and profiles for the study area. All of them are local people who live for generations in this Melaka heritage city.

Table 2: Backgrounds of the participants in Melaka City

\begin{tabular}{|c|c|c|c|c|c|c|}
\hline & erience & Age & $\operatorname{Sex}$ & Race & Religion & Nationality \\
\hline $\begin{array}{l}\text { The urban } \\
\text { manager }\end{array}$ & 14 years & 42 y.o & Male & Malay & Muslim & \multirow{5}{*}{$\begin{array}{l}\text { Malaysian / local people } \\
\text { living for generation }\end{array}$} \\
\hline $\begin{array}{l}\text { The city } \\
\text { journalist }\end{array}$ & 3 years & $26 y . o$ & Male & Malay & Muslim & \\
\hline $\begin{array}{l}\text { The tourist } \\
\text { guide }\end{array}$ & 44 years & 54 y.o & Male & Eurasian & Christian & \\
\hline $\begin{array}{l}\text { The boat } \\
\text { skipper }\end{array}$ & 6 years & 60 y.o & Male & Malay & Muslim & \\
\hline $\begin{array}{l}\text { The rickshaw } \\
\text { puller }\end{array}$ & 23 years & 53 y.o & Male & Malay & Muslim & \\
\hline
\end{tabular}

The findings in Figure 4 and Figure 5 reveals that the participants' movement expands beyond the preliminary boundary estimated prior to the ELS research via online and site exploration. It was found that the working communities' urban 
Nor Arbina Zainal Abidin, Debra Flanders Cushing and Gillian Lawson

Working Communities' Significant Heritage Urban River Corridor Landscape of Melaka City

river corridor territory includes all the natural and built water-related landscape settings that provide value and support for their working routines and personal needs. This research has discovered the characteristics of every important urban river corridor settings within the identified territory, including the natural, historical built and contemporary built settings. Table 3 summarizes the types of important settings of urban river corridors as perceived by working communities at Melaka City.

Table 3: Types of important settings within the working communities' urban river corridor territories

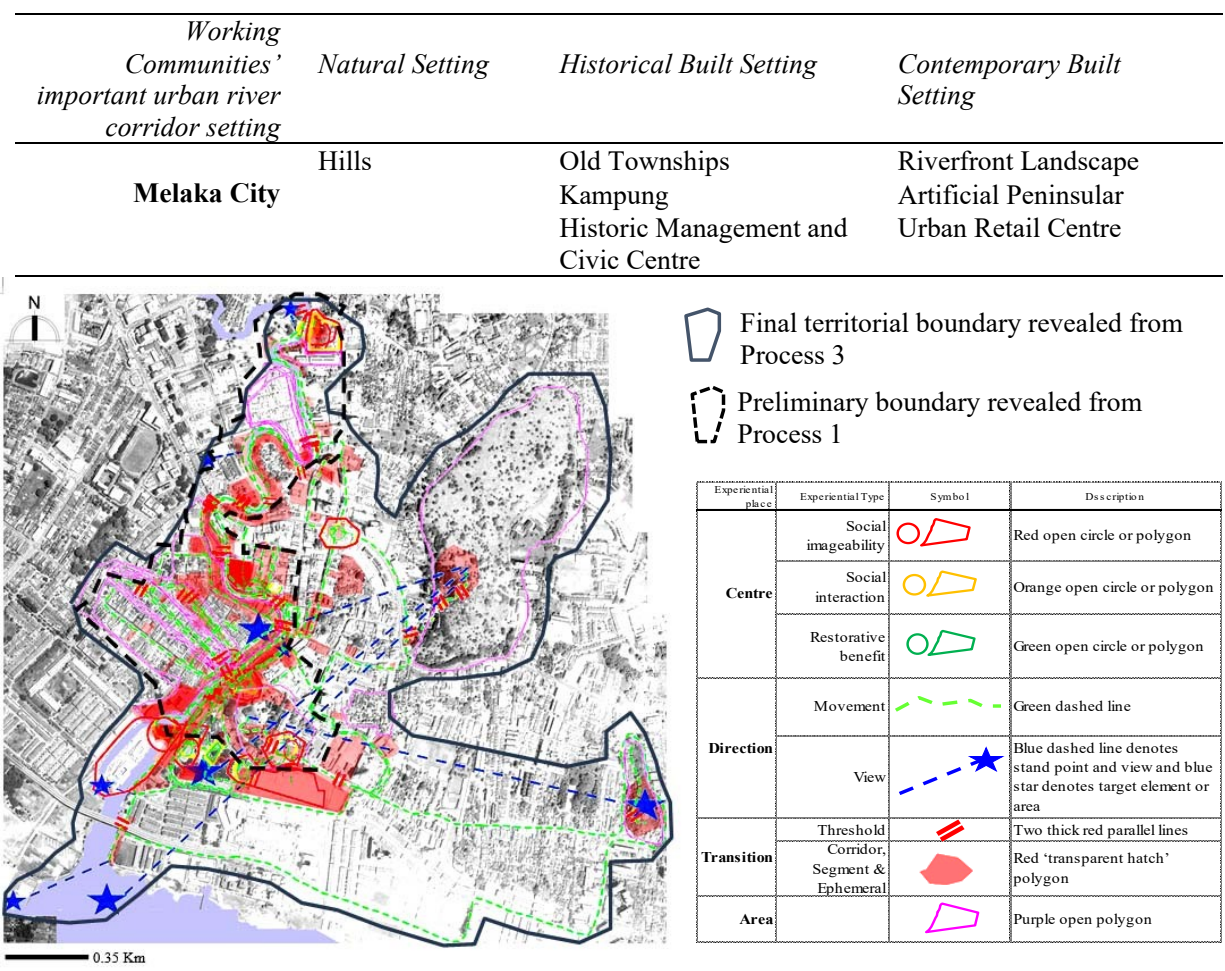

Figure 4: The boundary that defines the main territory of working communities' important urban river corridor landscape for Melaka City. 

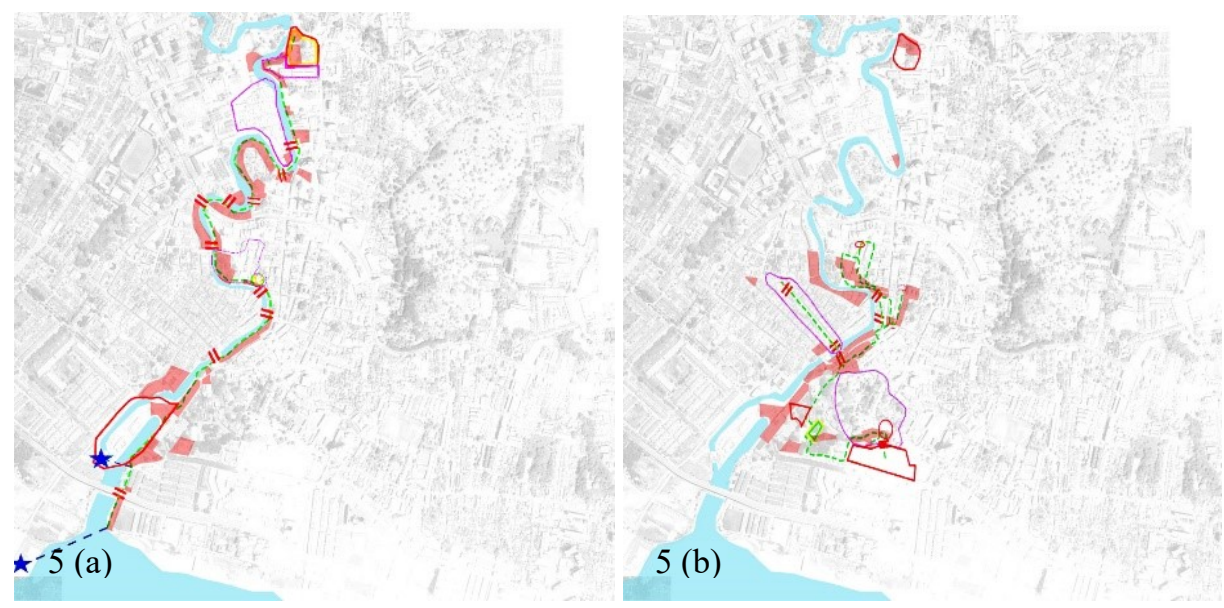

Figure 5 (a): The distribution patterns of important landscape settings that are individually significant to the urban manager.

Figure 5 (b): The distribution patterns of important landscape settings that are individually significant to the city journalist.
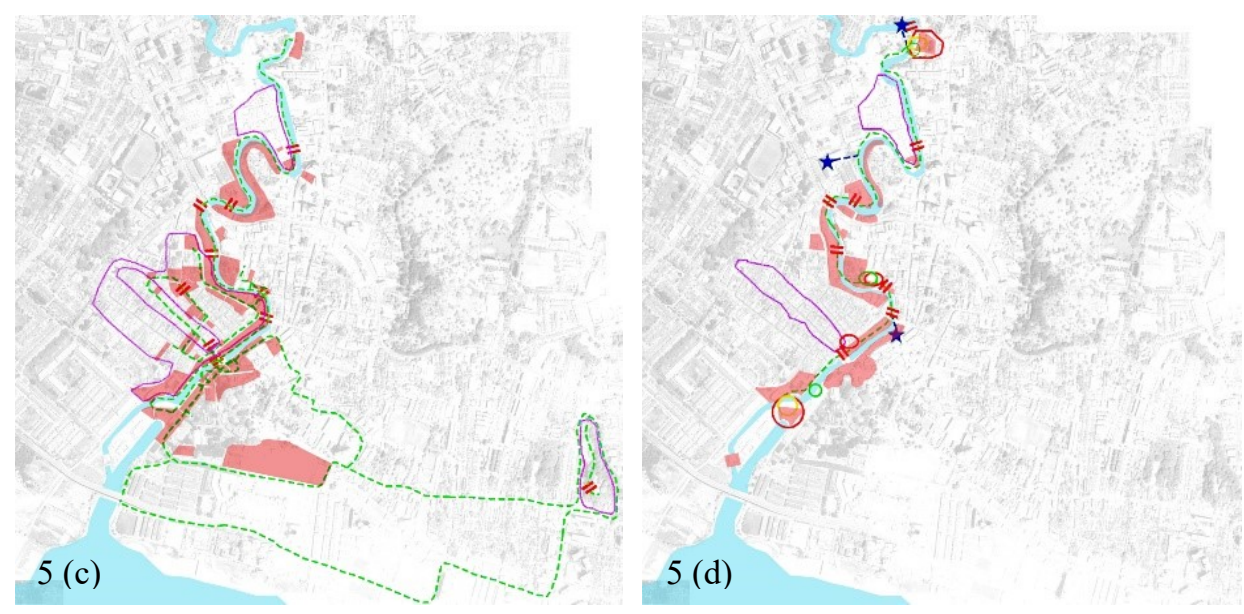

Figure 5 (c): The distribution patterns of important landscape settings that are individually significant to the tourist guide.

Figure 5 (d): The distribution patterns of important landscape settings that are individually significant to the boat skipper. 
Nor Arbina Zainal Abidin, Debra Flanders Cushing and Gillian Lawson

Working Communities' Significant Heritage Urban River Corridor Landscape of Melaka City

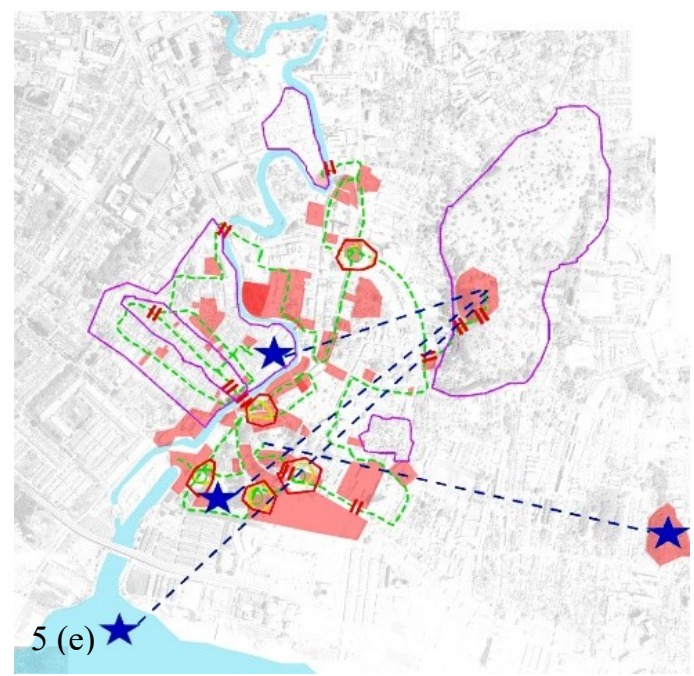

Figure 5 (e): The distribution patterns of important landscape settings that are individually significant to the rickshaw puller.

The findings show that the important urban river corridor territory perceived by the working communities in Melaka City includes various types of dominant natural settings as well as historical and contemporary built settings. Hills are a natural component in a natural setting that is found significant in providing sources of nature, culture, history and scenic attraction that are important to some of the working communities' working routines, particularly for those related to tourism activities, such as the city journalist, the tourist guide and the rickshaw puller. Old townships, kampung, and colonial management and civic center are the three historical developments that are found outstanding in the historical built setting in urban river corridor of Melaka City. This research also discovered that riverfront landscape, artificial peninsular and urban commercial center are the main types of developed settings in contemporary built settings of urban river corridor that are important to working communities of urban river corridor in Melaka City.

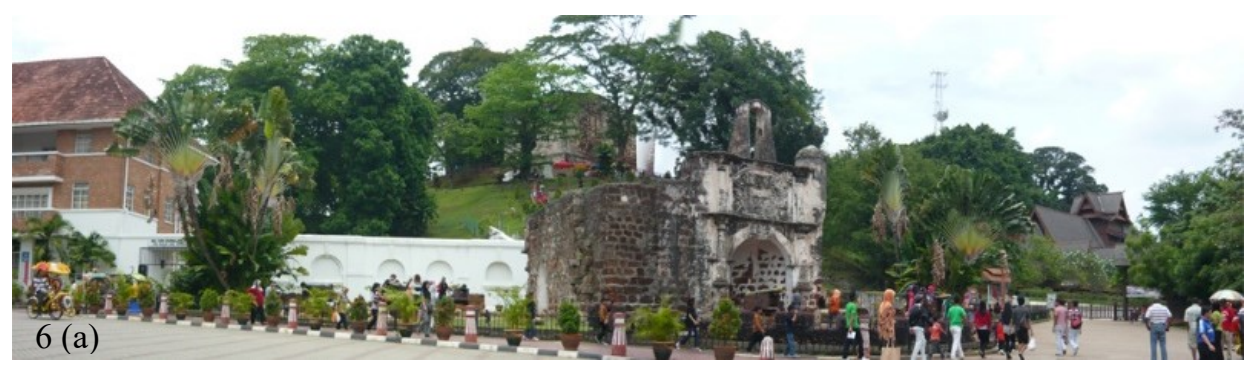


Figure 6 (a): St. Paul Hill is perceived as one of the important natural settings in the middle of the city by working communities.

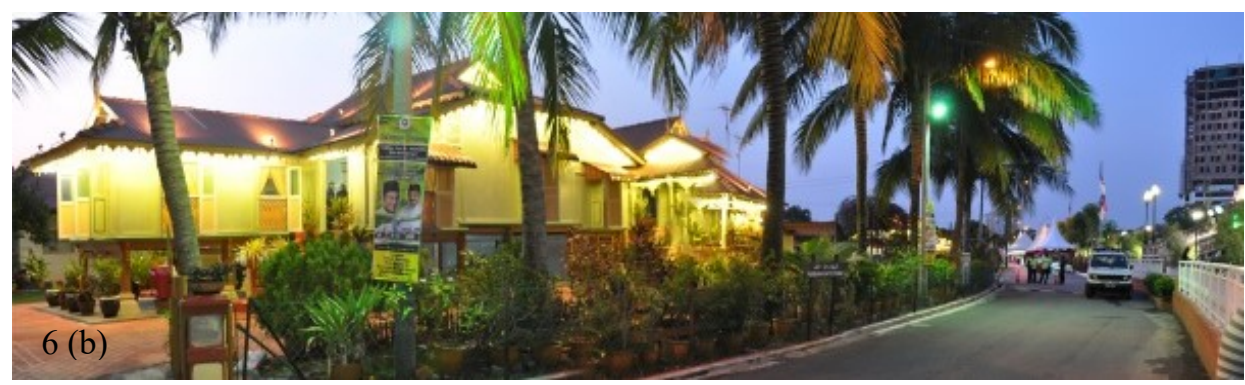

Figure 6 (b): Kampung Morten is perceived as one of important built historical settings by the working communities.

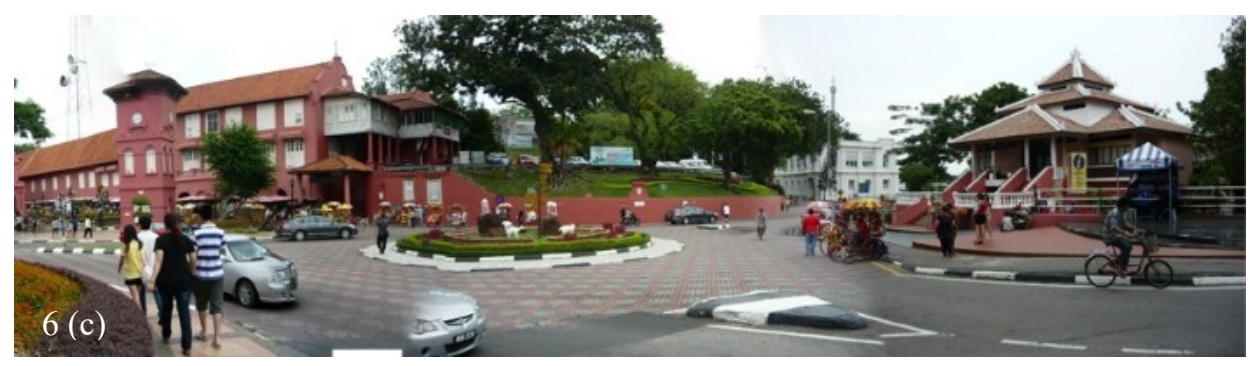

Figure 6 (c): The historic management and religions buildings within the civic center zone of Melaka City is perceived as one of the important historical built settings by working communities in this city.

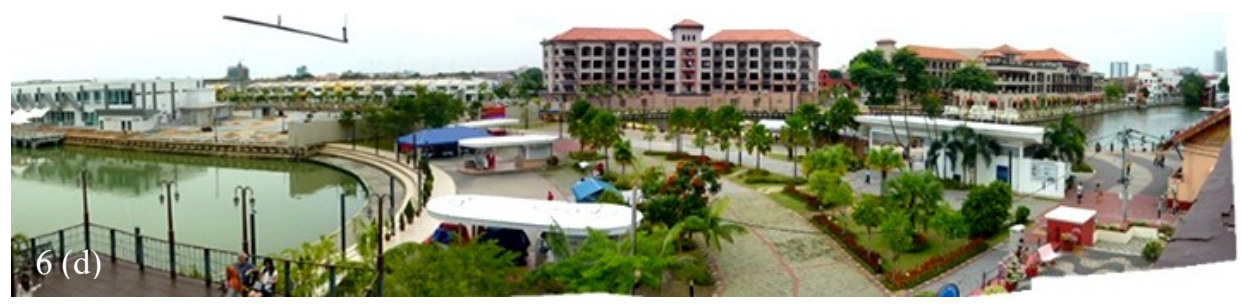

Figure 6 (d): The riverfront landscape area near to Sungai Melaka estuary is perceived as one of the important contemporary built settings by working communities.

The participants in Melaka City also have demonstrated their attachment and appreciation most to the historic management and civic center - Bandar Hilir area, due to its strong heritage significance. However, they are also had similar 
Nor Arbina Zainal Abidin, Debra Flanders Cushing and Gillian Lawson

Working Communities' Significant Heritage Urban River Corridor Landscape of Melaka City

perceptions about how kampung which this research classifies as a type of historical built setting have significant influences on their working routines. All these settings are found scattered throughout and beyond the preliminary boundary defined earlier in the research, which was based on the researcher's observations conducted during Stage 1 . The core boundary that defines the genuine territory of working communities' important urban river corridor landscape for Melaka City is finally revealed from the ELS, in-depth interview and mapping activities.

\section{DISCUSSION}

The findings revealed that the urban river corridor in Melaka City possessed a form of urban river corridor boundary that is significant in influencing the working communities' routine and their living survival in the settings. Using the ELS approach, this research found that the working communities' movements and routine settings expand beyond the preliminary boundary determined during the preliminary research stages via on-line and on-site exploration (Refer Figure $3)$.

This research discovered that the working communities' important urban river corridor territory in Melaka City also includes all the natural and built water-related landscape settings that are perceived as valuable in supporting their working routines and personal needs in the settings. The findings also showed that a boundary of important the urban river corridor in Melaka City is unique in aspects of it physical and geographical forms, size and area coverage, as well as the complexity of their characteristics.

The identified boundary is also expanded beyond the federal's technical river corridor boundary as specified by the DID in the Riverfront Development Guideline 1996. These findings also reject the terminology used to specify the technical boundary of river corridors in the Malaysian context developed by the DID which is stated as: "the river, including the area extending fifty (50) meters beyond the river reserve on both sides". On the one hand, this terminology offers a clear understanding of the technical condition of urban river corridors in the Malaysian context that significantly assist the way urban river corridors in Malaysia are sustained and managed. On the other hand, this terminology has been widely referred to, and used, by local urban managers and design teams in their urban river corridor development decisions and activities that have rigidly influenced the way they design. Further, they have encouraged unsustainable responses to the places in question. As such, the boundaries of river corridors have been seen, and treated, as standard in form and design approach in the Malaysian context. 
PLANNING MALAYSIA

Journal of the Malaysia Institute of Planners (2020)

\section{ACKNOWLEDGEMENTS}

The author would like to thank the School of Housing, Building and Planning, Universiti Sains Malaysia (USM) and the Ministry of Higher Education Malaysia for sponsoring the research.

\section{REFERENCES}

Earth, G. (Cartographer). (2017). Melaka, Malaysia. Retrieved from http://maps.google.com/

Forman, R. T. T. (1995). Stream and river corridors Land Mosaic: The Ecology of Landscapes and Region (pp. 208-252). Cambridge: Cambridge University Press.

Malaysia, D. I. D. (2006). Garis panduan Konsep Pembangunan Berhadapan Sungai.

Mohamad, S., Toriman, M. E., Aiyub, K., \& Jaafar, M. (2005). Sungai \& Pembangunan Tebing Sungai Bandar Malaysia (Rivers \& The Development of Malaysian Urban River Corridors). Bangi, Selangor: Universiti Kebangsaan Malaysia.

Nordin, E. A. (1998). Sungei Melaka: The past and present. (Architecture), Institut Teknologi Mara, Shah Alam.

Rustam, M. A. (2007). Foreword YAB Datuk Seri Hj Mohd Ali Rustam Sungai Melaka: The Rejuvenation of a National Cultural Heritage (pp. 6). Melaka city: Pesona Metro Sdn Bhd.

Rustam, M. A. (2008). Livable Cities for Tomorrow: City of Historic Melaka's Experience. Malacca City Malaysia: Minister of Melaka, Malaysia.

Salim, N., Othman, A. G., Mohamed, B., \& Ismail, H. N. (2012). Heritage Awareness Among Tour Operators in Heritage Sites: A Case Study of Rickshaw Pullers in Melaka. Paper presented at the 3rd International Conference on Business and Economic Research (3rd ICBER 2012) Proceeding, Bandung Indonesia.

SMHB. (2010). Sungai Melaka Rehabilitation and Beautification Project [Site photographs]. Melaka: SMHB.

Thwaites, K., \& Simkins, I. (2007a). Reading the experiantial landscape. In K. Thwaites, S. Porta, O. Romice, \& M. Greaves (Eds.), Experiential Landscape: An approach to people, place and space (pp. 79-108). New York: Routledge Taylor \& Francis Group.

Thwaites, K., \& Simkins, I. (2007b). The Vocabulary of Experientiential Landscape Experiential Landscape: An approach to people, place and space. Great Britain: Routledge Tylor and Francis Group.

Received: January 2020. Accepted: $22^{\text {th }}$ May 2020 